\title{
Meningeal Sarcomas
}

\section{Behzad Saberi* \\ Medical Research, Esfahan, Iran}

Submission: December 04, 2019; Published: December 13, 2019

${ }^{*}$ Correspondence Author: Behzad Saberi, Medical Research, Esfahan, Iran

\section{Mini Review}

Mesenchymal tissue is the origin of sarcomas. Brain sarcomas are usually in continuity with the dura. Intraparenchymal sarcomas also exist because the tela choroida and blood vessels have the mesenchymal origin [1]. Metastatic sarcoma is the differential diagnosis of such tumors which requires investigation to find a primary sarcoma in a place outside of the CNS. It is because true intracranial sarcomas are rarely found [2]. Classification of the tumors of the soft tissue which would arise from a site outside of the CNS, would be the base for classifying such tumors pathologically $[3,4]$. Intracranial sarcomas can be classified into various groups which are distinct from each other including gliosarcoma, sarcoma in the context of meningioma, skull and scalp originated sarcomas with extensions intracranially, de novo primary brain sarcomas, benign tumors which simulate sarcomas like desmoplastic infantile ganglio-glioma, benign fibrous histiocytoma and superficial cerebral astrocytoma, metastases from primary tumors which are located outside of the brain and post CNS radiotherapy treatment sarcomas [5-8].

Radical surgical excision would be the treatment method for such tumors. Chemotherapy and radiotherapy can be added to the surgical treatment. These tumors have high rates of brain invasion which such parenchymal invasions require the unaffected part of the brain to be sacrificed, in case of surgical trying for total excision of the tumors. Even with trying for aggressive resection of the tumors, local recurrence would happen. Also, metastatic disease is common in such tumors. These make the survival periods of the patients with such tumors short.

\section{References}

1. Paulus W, Scheithauer BW (2000) Mesenchymal, nonmeningothelial tumours. In: Kleihues P, Cavenee WK (eds) Pathology and Genetics of Tumours of the Nervous System. IARC Press Lyon, pp. 185-189.

2. Jellinger K, Paulus W (1991) Mesenchymal, non-meningothelial tumors of the central nervous system. Brain Pathol 1(2): 79-87.

3. Hope AJK, Armstrong DA, Babyn PS, Robin R Humphreys, Derek C Harwood-Nash (1992) Primary meningeal tumours in children correlation of clinical and CT findings with histologic type and prognosis. AJNR 13: 1353-1364.

4. Onofrio BM, Kernohan JW, Uihlein A (1962) Primary meningeal sarcomatosis. Cancer 15: 1197-1207.

5. Haddad GF, Al-Mefty O (1995) Meningeal sarcoma. In: Kaye AH, Laws ERJ (eds) Brain Tumors. An Encyclopedic Approach. Churchill Livingstone, Edinburgh, pp. 713-721.

6. Nakamura Y, Becker LE (1985) Meningeal tumors of infancy and childhood. Pediatr Pathol 3: 341-358.

7. Bojsen-Moller M, Knudsen V (1977) Radiation-induced meningeal sarcoma. A case report with a review of the literature. Acta Neurochir 37(1-2): 147-152.

8. Rueda-Franco F, Lopez-Corella E (1995) Sarcomas in the central nervous system of children. Pediatr Neurosurg 22: 49-56. 
This work is licensed under Creative Commons Attribution 4.0 License

DOI: 10.19080/CTOIJ.2019.15.555910

\section{Your next submission with Juniper Publishers} will reach you the below assets

- Quality Editorial service

- Swift Peer Review

- Reprints availability

- E-prints Service

- Manuscript Podcast for convenient understanding

- Global attainment for your research

- Manuscript accessibility in different formats

( Pdf, E-pub, Full Text, Audio)

- Unceasing customer service

Track the below URL for one-step submission https://juniperpublishers.com/online-submission.php 